\title{
Author Correction: Community evaluation of glycoproteomics informatics solutions reveals high-performance search strategies for serum glycopeptide analysis
}

Rebeca Kawahara (D), Anastasia Chernykh (1), Kathirvel Alagesan, Marshall Bern (1D, Weiqian Cao (1), Robert J. Chalkley (D), Kai Cheng, Matthew S. Choo (D, Nathan Edwards, Radoslav Goldman, Marcus Hoffmann, Yingwei Hu, Yifan Huang, Jin Young Kim (D), Doron Kletter, Benoit Liquet, Mingqi Liu, Yehia Mechref, Bo Meng, Sriram Neelamegham (D, Terry Nguyen-Khuong (D, Jonas Nilsson (1), Adam Pap, Gun Wook Park, Benjamin L. Parker, Cassandra L. Pegg, Josef M. Penninger (1), Toan K. Phung (D), Markus Pioch, Erdmann Rapp (D), Enes Sakalli, Miloslav Sanda (D, Benjamin L. Schulz (D), Nichollas E. Scott (1D, Georgy Sofronov (D), Johannes Stadlmann, Sergey Y. Vakhrushev (D), Christina M. Woo (D), Hung-Yi Wu, Pengyuan Yang (D), Wantao Ying, Hui Zhang (D), Yong Zhang (D), Jingfu Zhao, Joseph Zaia (1), Stuart M. Haslam (10, Giuseppe Palmisano, Jong Shin Yoo, Göran Larson (1), Kai-Hooi Khoo (1), Katalin F. Medzihradszky, Daniel Kolarich (1), Nicolle H. Packer (1) and Morten Thaysen-Andersen (1)

Correction to: Nature Methods https://doi.org/10.1038/s41592-021-01309-x, published online 1 November 2021.

In the version of this article initially published, extraneous references 29, 44-47, 19-22 were listed in Extended Data Fig. 4 caption and ref. 48 was listed in Extended Data Fig. 7 caption. The references have been removed from the HTML and PDF versions of the article.

Open Access This article is licensed under a Creative Commons Attribution 4.0 International License, which permits use, sharing, adaptation, distribution and
reproduction in any medium or format, as long as you give appropriate credit to the original author(s) and the source, provide a link to the Creative Commons
license, and indicate if changes were made. The images or other third party material in this article are included in the article's Creative Commons license, unless
indicated otherwise in a credit line to the material. If material is not included in the article's Creative Commons license and your intended use is not permitted by statutory regula-
tion or exceeds the permitted use, you will need to obtain permission directly from the copyright holder. To view a copy of this license, visit http://creativecommons.org/licenses/
by/4.0/.
Published online: 10 December 2021
https://doi.org/10.1038/s41592-021-01368-0
C The Author(s) 2021

